\title{
The Czech Sociological Data Archive
}

The Sociological Data Archive (SDA) of the Institute of Sociology in Prague collects computerized data files from quantitative sociological surveys. Its main objective is to make Czech sociological data publicly available for academic, educational and other non-commercial purposes. Other activities of the SDA include the promotion of data dissemination and secondary data analysis, and support for special research projects. The SDA is the only institution of its kind in the Czech Republic.

\section{Institutional settings}

The SDA has been open to the general public since September 1998. It was established within the project "Social Trends" (Research - Archives - Publication Graduate Training) of the Institute of Sociology. The project was headed by Dr. Petr Mateju and sponsored by the Grant Agency of the Czech Republic.

Since 1999 the SDA has been an independent department of the Institute of Sociology, a non-profit social research organization operating within the Academy of Sciences of the Czech Republic. Between 1999 and 2000 the Grant Agency of the Czech Republic financed a new SDA project. Thanks to it, the SDA has developed into an infrastructure capable of providing data and other services on the customary level. In spring 2001 the SDA became a member of the CESSDA (Council of European Social Science Data Archives).

At present the SDA team includes three younger researchers; the archiving work is also supported by co-operation with other research teams of the Institute of Sociology. Current institutional settings of the SDA are defined in the Statute of the Institute and operational costs are covered from its budget.

\section{WWW links:}

SDA: http://archiv.soc.cas.cz/

Institute of Sociology: http://www.soc.cas.cz/

Social Trends: http://www.soc.cas.cz/trends/
History of the Czech social survey research and data archiving

The Czech social research has a long tradition, but the continuity of its development was deeply affected by the communist regime (1948 - 1989). The history of empirical surveys in former Czechoslovakia dates well before the 2nd World War (the 1930s). In 1946 the American Gallup Institute inspired the creation of the Institute of Public Opinion Research which started systematic opinion polling. In the 1950s, with the exception of official statistics all activities in the field of social research were stopped on account of ideological reasons. Sociology itself was denounced as a "bourgeois pseudoscience", and all sociological institutes and faculties were closed down. In the 1960s research activities had been reestablished, but after 1968 were restricted again during "normalization" and put under the control of the communist party.

The transformation of Czech academic institutions of social sciences began soon after the "Velvet Revolution" in 1989, but the results in some areas have not yet reached satisfactory levels. Furthermore, commercial survey research and public opinion polling on social topics has developed after 1989.

\section{Archiving data from survey research}

In the Czech Republic the SDA is the only institution which systematically provides access to data files from quantitative sociological surveys. Before its formation, data files from sociological research projects were usually under the control of individual research teams. There was no systematic index of existing files, and poorly protected data were at risk of being lost or damaged. People interested in a specific data file had to negotiate with its owners. The lack of documentation and unsuitable formats often made it difficult to gain immediate access to data.

A debate concerning the formation of a social data archive in former Czechoslovakia was opened in the late 60s. At that time, the first efforts to establish an archive were related to the re-birth of Czech sociology and the growing popularity of survey research. Unfortunately, after the Russian invasion in 1968 the communist control over social sciences was gradually reinforced. In the period of 1970 - 
1989 the idea of systematic social data archiving reemerged, but it did not find a wide support among social scientists in view of the danger of abusing data for the purposes of the communist regime. A serious discussion on the establishment of a publicly accessible data institution continued after 1989. There were several attempts to establish the archive, and finally, the project "Social Trends" was successful in concentrating the necessary financial, personnel and institutional means, brought former ideas to fruition and founded the archive.

\section{Official Statistics}

In the field of official statistics data services are provided by the Czech Statistical Office (CSU). The CSU publishes Statistical Yearbooks, regular reports entitled the Indicators of Economic and Social Developments in the Czech Republic, booklets "The Czech Republic in Figures", and a series of publications devoted to the labor market, family budgets, demography, etc. It is possible to access CSU's micro databases but it must be negotiated on an individual basis after contacting the Office. Several data modules from the surveys organized by the CSU are part of international programs of EUROSTAT, CEPS/INSTEAD, CESTAT, etc.

\section{Qualitative data}

In recent years two qualitative data archives have also been established. The Czech Archive of Qualitative Data and Documents at the School of Social Sciences of Masaryk University in Brno was opened in 1999. Its objective is to establish a publicly accessible information database of qualitative data collected in the Czech Republic. In 2000 a qualitative research project on "alternative culture" resulted in the establishment of the Digital Archive of Soft Data MEDARD at the Virtual Institute in Prague. Information on both archives is available online.

WWW links:

Czech Statistical Office (CSU): http://www.czso.cz

Czech Archive of Qualitative Data and Documents: http://www.fss.muni.cz/qarchiv/

MEDARD: http://medard.institut.cz/

\section{SDA: Archived data}

The SDA brings together computerized data files from quantitative sociological surveys. At present the data catalogue includes approximately 160 titles, some of which are, however, English versions of original Czech data sets. Data holdings include data files collected by the Institute of Sociology and other Czech organizations conducting statefinanced sociological research, data from Czech publicly available opinion polls and from international surveys with Czech participation. The main access to the data library and other SDA's services is provided on the Internet.
The data processing launched by the "Social Trends" project focused on comparative projects in which the Czech Republic has been participating since 1990 and on research monitoring the main trends of the development of social structures in the Czech Republic. The further collection of data files has been aimed at earlier research projects of the Institute of Sociology, and the SDA has also developed a co-operation with several other research institutes.

The current largest project concerns the archiving of data from the public opinion surveys of the former Institute for Public Opinion Research (IVVM) from the period 1990 2000. Since 1990 the IVVM has been organizing monthly public opinion surveys on attitudes to political, economical and social issues. 120 data files from regular surveys and approximately 50 data files from other IVVM research projects have been transferred to the SDA's library, the data have been transformed into the SPSS format, checked, cleaned and documented. A number of questionnaires from older surveys have to be scanned. The data files from surveys conducted in 2000 and 1999 have already been made available to the general public. Other files are under preparation.

\section{WWW links:}

SDA's data holdings: http://archiv.soc.cas.cz ...than continue into "DATA ARCHIVE"

CVVM - Centre for Public Opinion Research (former IVVM): http://www.soc.cas.cz/cvvm/

\section{Promotion of data dissemination and secondary data analyses}

SDA was founded relatively recently and the tradition of using data services has not yet fully developed in the Czech Republic. International networks of data services are also little known. Therefore, the Archive has to pay great attention to promoting secondary analysis and employment of the existing data sources.

SDA publishes information on available data services in scientific and other periodicals, provides information to universities and public sector institutions, and organizes public presentations of the Archive and data service networks. The team of the Archive also participates in the educational programs of Charles University in Prague. In 1999 a course "Social Data Archives" was lectured at the Faculty of Social Sciences of Charles University. The course will be taught again in the fall 2001.

SDA Info - Archive's Information Bulletin is issued four times a year in the Czech language and is distributed free of charge. SDA Info provides an outline of available services, gives a more detailed overview of the stored data and research projects, provides references to other social data sources and is dedicated to promoting secondary data analysis. 
SDA's Internet services provide an online access to a number of analytical publications and offer the option of ordering publications from the Institute of Sociology. The directory of references located on the SDA's server includes useful Internet links to other social data sources, Czech social science information, international survey researches, and general information on the Czech Republic.

In addition to these data services, the Archive has also become a source of more general information on Czech society and social science research. In some areas the Czech social science infrastructure has not yet been developed, and until recently the English language sources of general information on the Czech Republic were also limited. Especially for foreigners, it is sometimes hard to orient themselves in the available sources. As a result, the Archive often answers questions from completely different fields of interest than sociology.

\section{Support of special research projects}

SDA has co-operated in organizing research projects prepared within the Institute of Sociology - especially the Czech portion of international projects such as the International Social Survey Programme (ISSP), the Second International Adult Literacy Survey (SIALS), and the European Value Study (EVS).

\section{International collaboration}

The SDA has co-operated mainly with the Zentralarchiv für Empirische Sozialforschung (ZA) in Cologne and with the GESIS Branch Office in Berlin. Contacts have also been developed with the Centre for the Study of Public Policy at the University of Strathclyde in Scotland, TARKI Budapest and with the Department of Sociology at UCLA. Additionally, members of the archive's team participate in several international research projects. At present the SDA intends to join international networks of data services. In April 2001 the SDA became a member of CESSDA (Council of European Social Science Data Archives) and the application for membership in the IFDO (International Federation for Data Organisations) is planned for the near future.

\section{References:}

Krejci, Jindrich. 1999. "Sociological Data Archive in Prague”. ZA Information 45: 142-152. ISSN 0723-5607.

Krejci, Jindrich. 1999. SDA - Sociological Data Archive. A Library of Computerized Data Files from Sociological Surveys. Institute of Sociology, Prague.

Krejci, Jindrich. 1999. ÑSociological Data Archive“. In: Ten years of rebuilding capitalism: Czech society after 1989. Eds: Jiri VecernIk, Petr Mateju. Academia. Prague.

Krejcì, Jindrich. 1998. "Novy zdroj sociologickych dat" [A New Source of Sociological Data]. Sociologicky casopis 1998/3.
SDA Info 2000: No. 1 - 4. ISSN 1212-995X.

SDA Info 1999: No. 1/2 - 4. ISSN 1212-995X.

VecernÌk, Jiri. 2000. "Social Reporting in the Czech Republic since 1989: The Present State of Art”. EuReporting Working Paper No. 11.

1. Jindrich Krejci, Sociological Data Archive, Institute of Sociology of the Czech Academy of Sciences, Jilska 1, 110 00 Praha 1. Phone: +420 $222220098-0100$ ext. 231. Fax: +420 2 22221658. E-mail: krejci@soc.cas.cz 